Adhi, S.R. · T. Suganda

\title{
Potensi jamur rizosfer bawang merah dalam menekan Fusarium oxysporum f.sp. cepae, penyebab penyakit busuk umbi bawang merah
}

Sari. Penyakit busuk umbi yang disebabkan oleh Fusarium oxysporum f.sp. cepae (Foc) merupakan salah satu penyakit penting pada bawang merah. Pengendalian penyakit busuk umbi yang ramah lingkungan adalah dengan menggunakan pengendalian biologis. Tujuan dari penelitian ini adalah untuk mendapatkan isolat jamur asal rizosfer tanaman bawang merah yang memiliki sifat antagonis terhadap Foc. Penelitian dilaksanakan di Laboratorium Fitopatologi Departemen Hama dan Penyakit Tumbuhan, Fakultas Pertanian, Universitas Padjadjaran, pada bulan November 2017 hingga Januari 2018. Tahapan penelitian ini terdiri atas: (1) isolasi dari tanah rizosfer pertanaman bawang merah asal Desa Pelayangan Kabupaten Cirebon, (2) uji antagonisme secara in-vitro dengan menggunakan Rancangan Acak Lengkap (RAL), dan (3) uji kemampuan jamur rizosfer dalam memicu perkecambahan benih bawang merah. Dari hasil percobaan diperoleh 11 isolat jamur rizosfer yang terdiri atas genus Aspergillus, Penicillium, Paecilomyces, dan Trichoderma yang memiliki karakteristik mikroskopis yang berbeda satu sama lain. Hasil uji antagonisme menunjukkan bahwa 11 isolat jamur rizosfer yang diuji memiliki sifat antagonistik dan dapat menghambat jamur Foc secara in-vitro antara 65,58\% hingga 84,71\%. Isolat JRC1 (Aspergillus) dan JRC6 (Paecilomyces) memiliki sifat memicu perkecambahan benih bawang merah.

Kata kunci: Bawang merah · Jamur antagonis rizosfer • Busuk umbi $\cdot$ Fusarium oxysporum f.sp cepae

\section{The potential of shallot rhizospheric fungi in suppressing Fusarium oxysporum f.sp. cepae, the causal agent of basal rot disease}

\begin{abstract}
Basal rot caused by Fusarium oxysporum f.sp. cepae (Foc) is one of the important diseases in shallot. Biological control is one of the environmentally friendly control methods. The purpose of this research was to obtain isolates of rhizospheric fungi of shallot which were antagonistic against Foc. Research has been conducted at the Laboratory of Phytopathology Department of Plant Pests and Diseases, Faculty of Agriculture, Universitas Padjadjaran, from November 2017 up to January 2018. The research consisted of: (1) isolation of fungi from shallot rhizosphere soil of shallot plantation located at Desa Pelayangan Cirebon, West Java, (2) in-vitro antagonistic test using a completely randomized design (CRD), and (3) test the ability of selected fungal isolates to triggering shallot seed germination. The experiment obtained 11 isolates of the antagonistic rhizospheric fungi consisted of Aspergillus, Penicillium, Paecilomyces, and Trichoderma which have different microscopic characteristics. The results showed that antagonistic rhizospheric fungi inhibit the growth of Foc. Their inhibitions rate ranged from $65.58 \%$ to $84.71 \%$. The isolates of JRC1 (Aspergillus) and JRC6 (Paecilomyces) were able to trigger the germination of shallot seeds.
\end{abstract}

Keywords: Shallot • Antagonistic rhizospheric fungi • Basal rot • Fusarium oxysporum f.sp. cepae

Diterima : 31 Juli 2019, Disetujui : 21 Maret 2020, Dipublikasikan : 31 Maret 2020

doi: https://doi.org/10.24198/kultivasi.v19i1.22877

Adhi, S.R. · T. Suganda
Fakultas Pertanian Universitas Padjadjaran
Korespondensi: satriyo13001@mail.unpad.ac.id

Adhi, S.R. dan T. Suganda: Potensi jamur rizosfer bawang merah menekan Fusarium oxysporum f.sp. cepae, 


\section{Pendahuluan}

Bawang merah (Allium ascalonicum) adalah salah satu rempah penting yang digunakan sebagai penyedap masakan, bahan baku industri makanan, dan memiliki potensi menjadi obat herbal (Hakim et al., 2017). Selain itu, bawang merah memiliki nilai ekonomi yang tinggi jika ditinjau berdasarkan pemenuhan kebutuhan konsumsi nasional, sumber penghasilan dan peluang kerja bagi petani, serta berpotensi menjadi sumber devisa negara (BPPP, 2005).

Produktivitas bawang merah masih terbilang rendah. Produktivitas pada tahun 2013 hingga 2017 hanya berkisar 9,31 - 10,22 ton/ha dengan potensi produktivitas yang masih dapat dicapai hingga 20 ton/ha (Setiani et al., 2016; BPS, 2018b). Salah satu faktor pembatas usahatani bawang merah di antaranya adalah terdapat hama dan penyakit (Rahayu et al., 2018).

Fusarium oxysporum f.sp. cepae (Foc) merupakan salah satu patogen penting yang mampu menyebabkan penyakit busuk umbi pada bawang merah. Menurut Naqvi (2004) keberadaan penyakit busuk umbi mampu menyebabkan kehilangan hasil hingga 50\%. Keparahan penyakit pada sentra produksi bawang merah di Kabupaten Bantul, Kabupaten Brebes, dan Kabupaten Nganjuk dilaporkan sebesar 13,75 - 30\% (Wiyatiningsih et al., 2009).

Beberapa teknik pengendalian Foc dapat dilakukan dengan melakukan kegiatan rotasi tanaman, penggunaan kultivar tahan, pengendalian hayati, dan menggunakan fungisida (Naqvi, 2004). Kegiatan rotasi tanaman dapat dilakukan dengan tidak menanam tanaman bawang merah selama 4 tahun (Delahaut and Stevenson, 2004). Beberapa kultivar ternyata belum menunjukkan tingkat tahan sepenuhnya terhadap Foc pada setiap musim, sebagai contoh kultivar Tiron dan kultivar Bauji diduga tahan, serta kultivar Biru dan kultivar Pilip menunjukkan tingkat ketahanan yang rendah (Wiyatiningsih dkk., 2009). Selain itu, penggunaan fungisida secara langsung pada tanah tidak dianjurkan karena dapat menyebabkan pencemaran tanah dan menurunkan kesuburan tanah (Wightwick et al., 2010; Kumar et al., 2017).

Salah satu teknik pengendalian yang dinilai aman terhadap lingkungan adalah menggunakan pengendalian hayati memanfaatkan mikroorganisme antagonis. Keuntungan meng- gunakan mikroorganisme antagonis di antaranya adalah aman bagi manusia dan musuh alami, mampu mencegah terjadinya resurjensi organisme pengganggu tanaman (OPT), tidak menghasilkan residu, mampu menghemat biaya produksi dan sumbernya dapat diperoleh di sekitar pertanaman (Nurhayati, 2011). Mikroorganisme antagonis dapat diperoleh dari daerah rizosfer. Rizosfer adalah daerah di sekitar perakaran yang memiliki kondisi sifat cepat berubah, aktivitas mikroorganisme tinggi, dan populasi mikroorganisme yang tinggi jika dibandingkan dengan daerah non-rizosfer (Handelsman and Stabb, 1996).

Jamur antagonis asal rizosfer beberapa tanaman telah dilaporkan memiliki kemampuan dalam menekan penyakit tanaman. Putri et al. (2015) menemukan jamur genus Trichoderma, Penicillium, dan Chaetomium asal tanaman karet yang memiliki kemampuan menekan 18,07$51,08 \%$ perkembangan penyakit lapuk fusarium tanaman karet. Selain itu Kurniati dan Ali (2018) mendapatkan 16 isolat jamur yang diisolasi dari rizosfer bawang merah dan memiliki kemampuan antagonis terhadap Alternaria porri sebesar 4,49-59,90\%. Meskipun telah dilaporkan kemampuan jamur antagonis asal rizosfer beberapa tanaman dalam menekan penyakit, potensi jamur yang memiliki sifat antagonis asal rizosfer tanaman bawang merah yang dapat menekan penyakit busuk umbi akibat Foc secara in-vitro belum banyak diketahui. Oleh karena itu, tujuan dari penelitian ini adalah untuk mendapatkan isolat jamur asal rizosfer tanaman bawang merah yang memiliki sifat antagonis terhadap Foc yang selanjutnya dapat dijadikan salah satu informasi alternatif pengendalian penyakit busuk umbi bawang merah menggunakan agensia hayati yang ramah lingkungan.

\section{Bahan dan Metode}

Penelitian ini dibagi menjadi empat tahapan percobaan, yaitu (1) pengambilan sampel tanah, (2) isolasi dan purifikasi jamur, (3) uji antagonistik secara in-vitro, dan (4) uji kemampuan jamur rizosfer dalam memicu perkecambahan benih bawang merah. Pengambilan sampel tanah rizosfer bawang merah dilakukan menggunakan metode purposive random sampling di Desa Pelayangan, Kecamatan Gebang, Kabupaten Cirebon, Provinsi Jawa Barat. Isolasi dan purifikasi jamur, pengujian antagonisme 
terhadap Foc serta uji kemampuan jamur rizosfer pada perkecambahan benih bawang merah dilakukan di Laboratorium Fitpatologi Departemen Hama dan Penyakit Tumbuhan, Fakultas Pertanian, Universitas Padjadjaran, dari bulan November 2017 sampai Januari 2018.

Pengambilan sampel tanah rizosfer. Pengambilan sampel tanah dilakukan dengan mengambil dua tanaman bawang merah yang tidak bergejala penyakit busuk umbi dari setiap bedengan, total tanaman yang diambil adalah 20 tanaman. Tanah diambil dengan menggunakan sekop kecil dengan kedalaman 10 - $15 \mathrm{~cm}$ dari pangkal batang dengan bobot masing-masing titik sampel $\pm 10 \mathrm{~g}$. Tanah yang sudah terkumpul kemudian dikompositkan dan dimasukkan ke dalam kantong plastik (Budiarti dan Nurhayati, 2014).

Isolasi dan identifikasi jamur rizosfer. Metode isolasi jamur menggunakan cara Purwantisari dan Hastuti (2009), yaitu mengambil komposit tanah rizosfer sebanyak 10 g kemudian disuspensikan dalam $100 \mathrm{ml}$ aquades steril lalu dikocok selama 20 menit menggunakan vortex, setelah itu sebanyak $1 \mathrm{ml}$ suspensi dipindahkan ke dalam $9 \mathrm{ml}$ aquades steril dalam tabung reaksi lalu dikocok hingga homogen (pengenceran tahap I atau10-1), pengenceran yang sama dilakukan sampai pengenceran $10^{-4}$. Hasil setiap pengenceran $10^{-1}$ hingga $10^{-4}$ masing-masing diambil $1 \mathrm{ml}$ dan dimasukkan ke dalam cawan Petri menggunakan pipet steril secara aseptik, kemudian ditambahkan media Potato Dextrose Agar (PDA), yang selanjutnya dihomogenkan dengan menggoyangkan cawan Petri hingga suspensi merata pada media, kemudian diinkubasikan pada $28^{\circ} \mathrm{C}-30^{\circ} \mathrm{C}$ (suhu kamar) selama $5-7$ hari. Pemurnian dilakukan pada setiap koloni jamur yang dianggap berbeda berdasarkan morfologi, warna, dan bentuk koloni yang terlihat dalam cawan Petri. Masing-masing koloni yang berbeda diambil menggunakan ose, kemudian ditumbuhkan kembali dalam cawan Petri berisi media PDA.

Identifikasi dilakukan secara makroskopis dan mikroskopis. Morfologi koloni dan hasil pengamatan mikroskopis dibandingkan dengan bantuan buku Illustrated Genera of Imperfect Fungi karangan Barnett and Hunter (1987).

Uji antagonisme metode dual culture. Uji antagonisme dilakukan dengan menumbuhkan isolat jamur rizosfer dengan jamur patogen secara berhadapan yang berjarak $3 \mathrm{~cm}$ pada cawan Petri berdiameter $9 \mathrm{~cm}$ berisi media PDA. Biakan uji diinkubasi pada suhu kamar (28 - 30 $\left.{ }^{\circ} \mathrm{C}\right)$ hingga patogen tumbuh memenuhi cawan Petri. Rancangan perobaan yang digunakan adalah Rancangan Acak Lengkap (RAL) dengan 12 perlakuan diulang 3 kali. Perlakuan adalah 11 jamur rizosfer ditambah dengan tanpa jamur rizosfer (kontrol).

Uji kemampuan jamur rizosfer dalam memicu perkecambahan benih bawang merah. Dilakukan dengan menggunakan metode Zulaika (2014) yang dimodifikasi, yaitu benih bawang merah varietas Tuk-Tuk disterilisasi permukaan menggunakan natrium hipoklorit $1 \%$ selama 2 menit, kemudian dibilas menggunakan aquades steril sebanyak 3 kali dan selanjutnya dikeringanginkan. Kemudian benih dikecambahkan pada rockwool steril di dalam botol kultur yang di dalamnya sudah berisi masing-masing biakan jamur rizosfer.

Pengamatan dan analisis data. Pengamatan antagonisme jamur rizosfer terhadap Foc dilakukan pada 7 hari setelah inkubasi, dengan mengukur jari-jari koloni jamur rizosfer pada cawan Petri. Data hasil pengukuran jari-jari koloni jamur dimasukan ke dalam rumus persentase penghambatan sebagai berikut.

Penghambatan $(\%)=\frac{b-a}{b} \times 100 \%$

Keterangan

a: jari-jari perlakuan jamur rizosfer

b: jari-jari koloni perlakuan kontrol (Foc)

Pengamatan perkecambahan benih bawang merah di atas biakan jamur rizosfer dilakukan pada hari ke sepuluh. Komponen yang diamati adalah jumlah benih bawang merah yang berkecambah, gejala nekrosis pada kecambah, dan membandingkan pertumbuhan kecambah benih bawang merah.

Nilai persentase penghambatan selanjutnya dianalisis menggunakan analisis sidik ragam (Anova) pada taraf nyata 5\% menggunakan program SPSS 21. Kemudian jika hasil uji F yang diperoleh berbeda nyata, maka dilakukan uji lanjut dengan uji Scott-Knott taraf nyata 5\% menggunakan program SASM-Agri.

\section{Hasil dan Pembahasan}

Karakteristik dan identifikasi jamur rizosfer. Hasil isolasi dan purifikasi jamur rizosfer asal tanaman bawang merah menghasilkan 11 isolat 
jamur bergenus Aspergillus, Paecilomyces, Penicillium, Trichoderma, dan satu isolat belum teridentifikasi (Tabel 1). Sebelas isolat jamur rizosfer tersebut memiliki karakteristik mikroskopis yang berbeda satu sama lain (Gambar 1).

Tabel 1. Hasil isolasi dan purifikasi jamur rizosfer bawang merah.

\begin{tabular}{cc}
\hline Kode & Genus \\
\hline JRC1 & Aspergillus \\
JRC2 & Penicillium \\
JRC3 & Penicillium \\
JRC4 & Aspergillus \\
JRC5 & Aspergillus \\
JRC6 & Paecilomyces \\
JRC7 & Belum teridentifikasi \\
JRC8 & Paecilomyces \\
JRC9 & Penicillium \\
JRC10 & Penicillium \\
JRC11 & Trichoderma \\
\hline
\end{tabular}

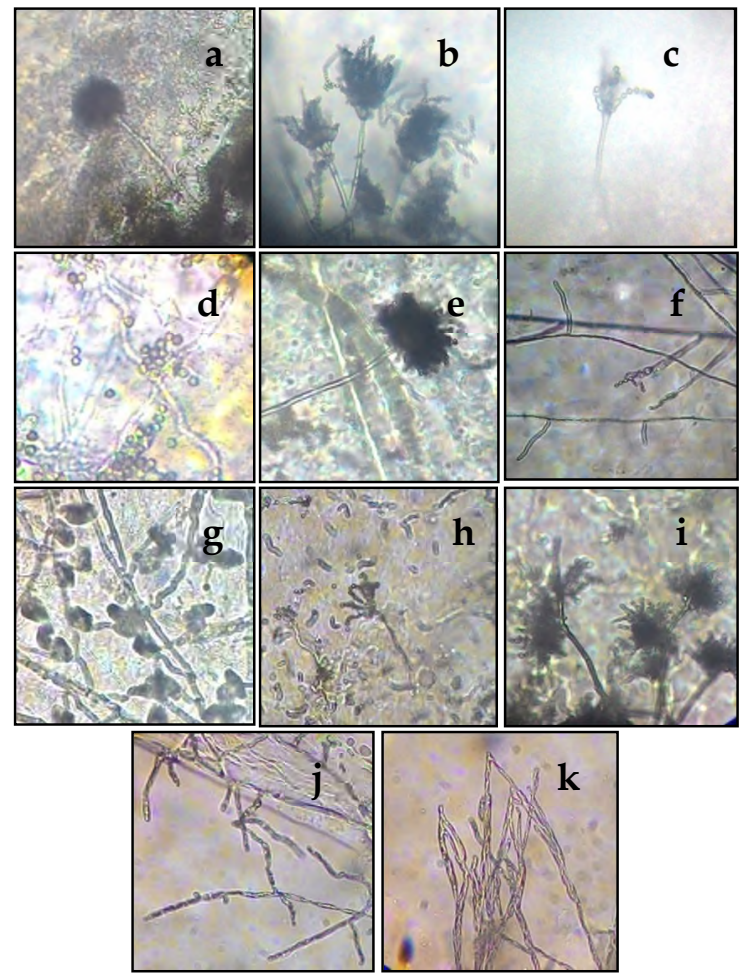

Gambar 1. Karakteristik mikroskopis isolat jamur rizosfer bawang merah (a) JRC1, (b) JRC2, (c) JRC3, (d) JRC4, (e) JRC5, (f) JRC6, (g) JRC7, (h) JRC8, (i) JRC9, (j) JRC10, dan (k) JRC11.

Keanekaragaman mikroorganisme tanah akan sangat dipengaruhi oleh komposisi kimia eksudat tanaman. Menurut Bashir et al. (2016) eksudat akar memengaruhi jumlah populasi mikroorganisme. Daerah rizosfer juga memiliki aktivitas mikroorganisme yang tinggi jika dibandingkan dengan daerah non-rizosfer (Handelsman and Stabb, 1996). Selain itu, keanekaragaman mikroorganisme di tanah rizosfer akan bergantung pada faktor seperti spesies tanaman, stadia tumbuh tanaman, dan jenis tanah (Nihorimbere et al., 2011).

Lokasi pengambilan sampel tanah rizosfer yang diperoleh dari Desa Pelayangan Kabupaten Cirebon menurut Balittanah (2007) akan memiliki dua jenis tanah yaitu Gleisol Vertik dan Aluvial Hidrik. Ciri tanah Gleisol Vertik adalah berwarna keabuan, teksturnya sangat halus, drainasenya terhambat, sangat liat dan plastis, sedangkan ciri tanah Aluvial Hidrik adalah berlumpur, berwarna abu-abu yang mengarah ke biru atau hijau, drainasenya sangat terhambat, tekstur tanah sangat halus dan $\mathrm{pH}$ cenderung basa $(>6,5)$. Menurut Rousk et al. (2010) keberadaan spesies jamur biasanya memiliki kisaran $\mathrm{pH}$ optimum yang luas yaitu sekitar 5 - 9 .

Penekanan jamur rizosfer terhadap Foc. Semua isolat jamur rizosfer bawang merah memiliki kemampuan menekan pertumbuhan Foc patogen secara in-vitro dengan persentase penghambatan antara $65,58-84,71 \%$ (Tabel 2). Menurut Whipps (2001) mekanisme jamur antagonis di antaranya yaitu kompetisi, antibiosis, induksi resistensi, mikoparasit, dan plant growth promotion. Kompetisi ditandai dengan adanya perebutan ruang dan nutrisi oleh dua mikroorganisme. Kecepatan pertumbuhan pada salah satu jamur akan mampu menguasai ruang media dan dapat menekan pertumbuhan jamur lawan (Purwantisari dan Hastuti, 2009). Kompetisi memperebutkan karbon, nitrogen, dan besi telah terbukti menjadi mekanisme agen pengendali hayati (Whipps, 2001).

Tingkat persentase penghambatan yang berbeda oleh masing-masing isolat jamur rizosfer bawang merah terhadap pertumbuhan koloni Foc disebabkan adanya perbedaan kemampuan antagonisme. Hal ini juga berhasil dibuktikan pada hasil pengamatan interaksi jamur rizosfer dengan Foc secara mikroskopis (Gambar 2). Jamur rizosfer genus Aspergillus (JRC1, JRC4, dan JRC5) menyebabkan lisis dan melanisasi pada Foc (Gambar 2A). Genus Penicillium (JRC2, JRC3, JRC9, dan JRC10) dan genus Trichoderma (JRC11) diduga memiliki kemampuan parasitasi yaitu ditandai dengan 
hifa jamur rizosfer yang membelit hifa Foc (Gambar 2B). Isolat jamur rizosfer genus Paecilomyces (JRC6 dan JRC8) diduga memiliki mekanisme antibiosis yang ditandai dengan abnormalitas dan melanisasi pada hifa Foc (Gambar 2D \& 2E).

Tabel 2. Persentase penghambatan jamur rizosfer pada Foc.

\begin{tabular}{cc}
\hline Perlakuan & $\begin{array}{c}\text { Pengham } \\
\text { batan (\%) }\end{array}$ \\
\hline Kontrol (Foc) & $0 \quad \mathrm{a}$ \\
JRC1 (Aspergillus) + Foc & $72,20 \mathrm{~b}$ \\
JRC2 (Penicillium) + Foc & $77,55 \mathrm{c}$ \\
JRC3 (Penicillium) + Foc & $80,07 \mathrm{c}$ \\
JRC4 (Aspergillus) + Foc & $84,71 \mathrm{c}$ \\
JRC5 (Aspergillus) + Foc & $83,21 \mathrm{c}$ \\
JRC6 (Paecilomyces) + Foc & $77,59 \mathrm{c}$ \\
JRC7 (Belum teridentifikasi) + Foc & $78,19 \mathrm{c}$ \\
JRC8 (Paecilomyces) + Foc & $82,02 \mathrm{c}$ \\
JRC9 (Penicillium) + Foc & $65,58 \mathrm{~b}$ \\
JRC10 (Penicillium) + Foc & $69,85 \mathrm{~b}$ \\
JRC11 (Trichoderma) + Foc & $77,46 \mathrm{c}$ \\
\hline
\end{tabular}

Keterangan: Nilai penghambatan perlakuan yang diikuti oleh huruf yang dan pada kolom yang sama menunjukkan tidak berbeda nyata berdasarkan uji Scott-Knott pada taraf $5 \%$.

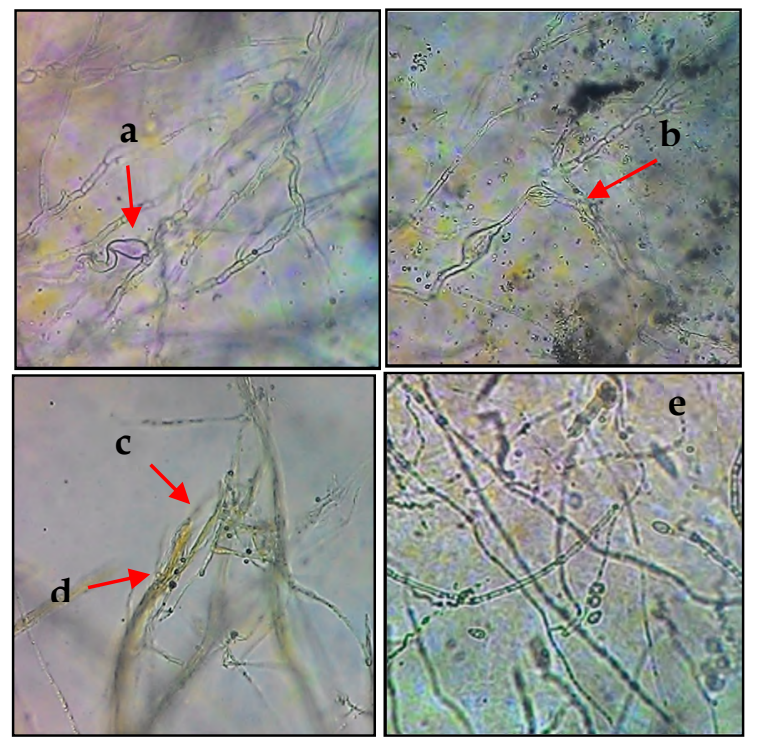

Gambar 2. Interaksi antagonistik jamur rizosfer bawang merah terhadap Foc secara mikroskopis (a) hifa Foc membengkak, (b) hifa jamur rizosfer membelit hifa Foc, (c) sel hifa mengalami abnormalitas, (d) melanisasi pada hifa Foc, (e) hifa Foc yang normal.

Melanisasi pada hifa Foc diduga disebabkan karena adanya pengaruh antibiosis akibat senyawa-senyawa kimia yang dihasilkan oleh jamur rizosfer. Siddiqui et al. (2004) melaporkan bahwa jamur Aspergillus sp. yang diisolasi dari rizosfer tanaman tomat, okra, terung, dan kacang hijau mampu menghasilkan senyawa metabolit sekunder seperti brevianamide, asam gladiolic, asam mycophenolic, asam canadensic, flavoskyrin, dehydrocanadensolide, asam $\alpha$ collatolic, dan asam tenuazonic. Selain itu Antifungal Protein (AFP) yang dihasilkan oleh A. giganteus mampu mendegradasi sel dan merusak plasma membran pada Magnaporthe grisea (Moreno et al., 2006). Pada jamur Penicillium juga mampu menghasilkan senyawa kimia anti-Fusarium yaitu dehydrocostus lactone dan iridoide glycoside (harpagoside) (Mousa et al., 2016). Mekanisme antibiosis oleh jamur Paecilomyces disebabkan adanya senyawa metabolit yang bersifat antifungal. Hal ini seperti yang dilaporkan Hussain et al. (2016) bahwa aplikasi konidia jamur Paecilomyces dengan kerapatan $10^{4} / \mathrm{ml}$ mampu menekan penyakit layu Fusarium tanaman cabai hingga 90,1\%.

Mekanisme antagonistik parasitasi disertai pelepasan senyawa metabolit juga dapat terjadi. Trichoderma memiliki kemampuan mikoparasitisme dan menghasilkan senyawa peptaibols, gliovirin, serta gliotoxin yang mampu menghambat pertumbuhan patogen (Keswani et al., 2014). Selain itu, Trichoderma mampu menghasilkan enzim pendegradasi sel yaitu kitinase, ß-1,3-glukanase, ß-1,6-glukanase, protease, selulase, dan lektin (Jayalaksmi et al., 2009; Rehman et al., 2012).

Pengaruh jamur rizosfer terhadap
perkecambahan benih bawang merah. Berdasarkan Tabel 3, diketahui terdapat 2 isolat jamur rizosfer (JRC1 dan JRC6) yang dapat memicu perkecambahan benih bawang merah. Selain itu, terdapat 6 isolat jamur rizosfer (JRC2, JRC3, JRC4, JRC5, JRC9, dan JRC10) yang dapat mengganggu perkecambahan benih bawang merah.

Isolat jamur rizosfer yang mampu memicu nilai persentase perkecambahan yang lebih tinggi jika dibandingkan perlakuan kontrol dapat terlihat pada isolat JRC1 (Aspergillus) dan JRC6 (Paecilomyces) (Gambar 2B \& 2C). Hal tersebut diduga disebabkan jamur rizosfer yang mampu menghasilkan senyawa-senyawa yang berperan sebagai pemacu pertumbuhan. Abri et al. (2015) melaporkan jika 19 isolat jamur rizosfer asal tanaman padi aromatik mampu menghasilkan hormon indole-3-acetic acid (IAA) 
sebesar 0,048 - 2,190 mg/L. Aspergillus niger mampu menghasilkan hormon IAA sebesar 85 $\mu \mathrm{g} / \mathrm{mL}$ (Yadav et al., 2011). Jamur Paecilomyces juga dilaporkan mampu menghasilkan fitohormon, pada $P$. formosus diketahui menghasilkan giberelin dan IAA (Khan et al., 2012).

Tabel 3. Persentase perkecambahan benih bawang diatas biakan jamur rizosfer.

\begin{tabular}{cc}
\hline Perlakuan & $\begin{array}{c}\text { Perkecambahan } \\
(\%)\end{array}$ \\
\hline Kontrol (PDA) & 80 \\
JRC1 (Aspergillus) & 90 \\
JRC2 (Penicillium) & 70 \\
JRC3 (Penicillium) & 60 \\
JRC4 (Aspergillus) & 50 \\
JRC5 (Aspergillus) & 60 \\
JRC6 (Paecilomyces) & 100 \\
JRC7 (Belum teridentifikasi) & 80 \\
JRC8 (Paecilomyces) & 80 \\
JRC9 (Penicillium) & 60 \\
JRC10 (Penicillum) & 10 \\
JRC11 (Trichoderma) & 80 \\
\hline
\end{tabular}

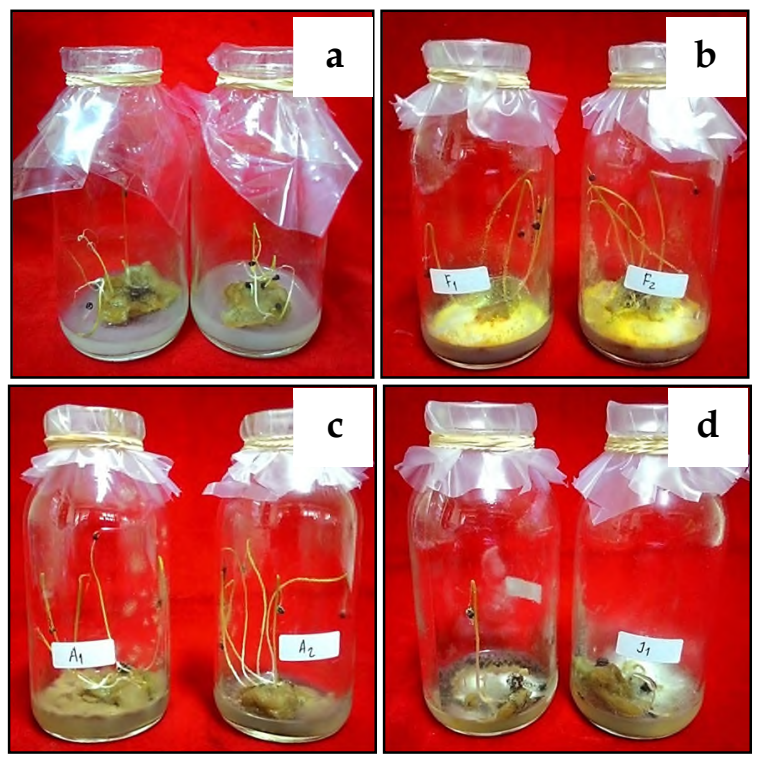

Gambar 3. Perkecambahan benih bawang merah di atas biakan jamur rizosfer (a) tanpa biakan jamur/kontrol, (b) perlakuan JRC6 Paecilomyces yang meningkatkan pertumbuhan, (c) perlakuan JRC1 Aspergillus yang meningkatkan pertumbuhan, dan (d) perlakuan JRC10 Penicillium yang memengaruhi perkecambahan.

Enam isolat jamur rizosfer (JRC2, JRC3, JRC4, JRC5, JRC9, dan JRC10) yang berasal dari genus Aspergillus dan Penicillium menyebabkan terganggunya perkecambahan pada benih bawang merah. Sebagian isolat tersebut diduga memiliki sifat sebagai jamur patogen penyebab penyakit di lapangan. Aspergillus niger dilaporkan dapat menjadi patogen penyebab penyakit busuk hitam pada golongan bawang (Prajapati and Patil, 2014). Sang et al. (2014) melaporkan bahwa Penicillium spp. mampu berperan sebagai penyakit pascapanen umbi bawang merah.

\section{Kesimpulan}

Dari sebelas isolat jamur telah diperoleh dari rizosfer pertanaman bawang merah. Semua isolat secara in-vitro bersifat antagonis terhadap Foc dengan penghambatan sebesar 65,58\% hingga $84,71 \%$. Berdasarkan hasil uji kemampuan jamur rizosfer dalam memicu perkecambahan benih bawang merah diperoleh 2 isolat dari genus Aspergillus dan Paecilomyces yang memiliki kemampuan memicu perkecambahan benih bawang merah dan berpotensi sebagai calon agen pengendali hayati jamur Foc patogen.

\section{Daftar Pustaka}

Abri., T. Kuswinanti, E.L. Sengin, and R. Sjahrir. 2015. Production of indole acetic acid (IAA) hormone from fungal isolates collected from rhizosphere of aromatic rice in Tana Toraja. Int. J. Curr. Res. Biosci. Plant Biol., 2(6): 198-201.

Balittanah. 2007. Teknologi Pemupukan Spesifik Lokasi dan Konservasi Tanah Desa Pelayangan Kecamatan Gebang Kabupaten Cirebon. Balai Besar Penelitian dan Pengembangan Sumberdaya Lahan Pertanian. Bogor.

Barnett, H.L., and B.B. Hunter. 1987. Illustrated Genera of Imperfect Fungi. 4th ed. Macmillan Publishing Company. New York.

Bashir, O., K. Khan, K.R. Hakeem, N.A. Mir, G.H. Rather, and R. Mohiuddin. 2016. Soil microbe diversity and root exudates as important aspects of rhizosphere ecosystem. In: Hakeem, K.R. and Akhtar, M.S., editors, Plant, Soil and Microbes: Vol 2: Mechanisms and Molecular Interactions. Springer Int'l Publishing, Switzerland.

BPPP. 2005. Prospek dan Arah Pengembangan Agribisnis Bawang Merah. Badan Penelitian dan Pengembangan Pertanian. Jakarta. 
Budiarti, L., dan Nurhayati. 2014. Kelimpahan cendawan antagonis pada rhizosfer tanaman kacang panjang (Vigna sinensis (L.) Savi ex Hassk.) di lahan kering Indralaya Sumatera Selatan. Pros. Semin. Nas. Lahan Suboptimal $2014 \quad$ (26-27 September).

Delahaut, K.D., and W. Stevenson. 2004. Onion Disorder: Fusarium Basal Rot. University Winconsin. Madison.

Hakim, A.R., Rajiman, dan R. Nalinda. 2017. Analisis nilai ekonomi usahatani bawang merah (Alium cepa L.) off season dan in seasin pada lahan pasir pantai (studi kasus di Desa Srigading Kecamatan Sanden Kabupaten Bantul DIY). SEPA J. Sos. Ekon. Pertan. dan Agribisnis 14(1): 53-60. doi: 10.20961/sepa.v14i1.21046.

Handelsman, J., and E.V. Stabb. 1996. Biocontrol of soilborne plant pathogens. Plant Cell 8(10): 1855-1869. doi: 10.2307/3870235.

Hussain, I., S.S. Alam, I. Khan, B. Shah, A. Naeem, et al. 2016. Medicinal plants rhizosphere exploration for the presence of potential biocontrol fungi. J. Entomol. Zool. Stud., 4(3): 108-113.

Jayalaksmi, S.K., S. Raju, R.S. Rani, V.I. Benagi, and K. Sreeramulu. 2009. Trichoderma harzianum L1 as a potential source for lytic enzymes and elicitor of defense responses in chickpea (Cicer arietinum L.) against wilt disease caused by Fusarium oxysporum f. sp. ciceri. Aust. J. Crop Sci., 3(1): 44-52.

Keswani, C., S. Mishra, B.K. Sarma, S.P. Singh, and H.B. Singh. 2014. Unraveling the efficient applications of secondary metabolites of various Trichoderma spp. Appl. Microbiol. Biotechnol., 98(2): 533544. doi: 10.1007/s00253-013-5344-5.

Khan, A.L., M. Hamayun, S.M. Kang, Y.H. Kim, H.Y. Jung, et al. 2012. Endophytic fungal association via gibberellins and indole acetic acid can improve plant growth under abiotic stress: An example of Paecilomyces formosus LHL10. BMC Microbiol., 12(3): 1-14. doi: 10.1186/14712180-12-3.

Kumar, R.P.K., S.P. Niharika, and G. Hemanth. 2017. Impact of fungicides on the growth and distribution of soil mycoflora in agriculture fields at Narasannapeta. Int. J. Sci. Res., 6(1): 2337-2347. doi: 10.21275/art20164650.

Kurniati, A., and M. Ali. 2018. Isolasi dan uji antagonis jamur asal rizosfer tanaman bawang merah (Allium ascalonicum L.) terhadap Alternaria porri Ellis Cif. JOM Faperta UR 5(1): 1-9.

Moreno, A.B., A. Martinez, and B.S. Segundo. 2006. Biotechnologically relevant enzymes and proteins: Antifungal mechanism of the Aspergillus giganteus AFP against the rice blast fungus Magnaporthe grisea. Appl. Microbiol. Biotechnol., 72(5): 883-895. doi: 10.1007/s00253-006-0362-1.

Mousa, W.K., A.L. Schwan, and M.N. Raizada. 2016. Characterization of antifungal natural products isolated from endophytic fungi of finger millet (Eleusine coracana). Molecules, 21(9): 1-14. doi: 10.3390/molecules21091171.

Naqvi, S.A.M.H. 2004. Diseases of Fruits and Vegetables. Kluwer Academic Publishers. New York.

Nihorimbere, V., M. Ongena, M. Smargiassi, and P. Thonart. 2011. Beneficial effect of the rhizosphere microbial community for plant growth and health. Biotechnol. Agron. Soc. Environ., 15(2): 327-337.

Nurhayati. 2011. Penggunaan jamur dan bakteri dalam pengendalian penyakit tanaman secara hayati yang ramah lingkungan. Prosiding Semirata Bidang Ilmu-ilmu Pertanian BKS-PTN Wilayah Barat Tahun 2011. Universitas Sriwijaya. Palembang.

Prajapati, B.K., and R.K. Patil. 2014. Black mould rot: an important post harvest disease of onion and its management. Popular Kheti, 1(1): 162-163.

Purwantisari, S., and R.B. Hastuti. 2009. Isolasi dan identifikasi jamur indigenous rhizosfer tanaman kentang dari lahan abstrak. Bioma, 11(Desember): 45-53. doi: 10.14710/bioma.11.2.45-53.

Putri, W.K., S. Khotimah, and R. Linda. 2015. Jamur rizosfer sebagai agen antagonis pengendali penyakit lapuk Fusarium pada batang tanaman karet (Hevea brasiliensis MuellArg). Protobiont, 4(3): 14-18.

Rahayu, Mujiyo, and R.U. Arini. 2018. Land suitability evaluation of shallot (Allium ascalonicum L.) at production centres in Losari District, Brebes. J. Degrad. Min. L. Manag.5(53):2502-2458. doi: 10.15243/jdmlm.

Rehman, S.U., R. Lawrence, E.J. Kumar, and Z.A. Badri. 2012. Comparative efficacy of Trichoderma viride, T. harzianum and carbendazim against damping-off disease of cauliflower caused by Rhizoctonia solani 
Kuehn. JBiopest, 5(1): 23-27.

Rousk, J., E. Baath, P.C. Brookes, C.L. Lauber, C. Lozupone, et al. 2010. Soil bacterial and fungal communities across a $\mathrm{pH}$ gradient in an arable soil. ISME J., 4(10): 1340-1351. doi: 10.1038/ismej.2010.58.

Sang, M.K., G.D. Han, J.Y.Oh, S.C. Chul, and D.K. Kim. 2014. Penicillium brasilianum as a novel pathogen of onion (Allium cepa L.) and other fungi predominant on market onion in Korea. Crop Prot., 65 (August 2013): 138-142. doi:10.1016/j.cropro.2014.07.016.

Setiani, R., D. Mulyono, dan Nurmalinda. 2018. Strategi pengembangan bawang merah di Kabupaten Bima, Nusa Tenggara Barat. J. Ekon. dan Pembang. 26(2): 143-152.

Siddiqui, I.A., S.S. Shaukat, and A. Khan. 2004. Differential impact of some Aspergillus species on Meloidogyne javanica biocontrol by Pseudomonas fluorescens strain CHA0. Lett. Appl. Microbiol., 39(1): 74-83. doi: 10.1111/j.1472-765X.2004.01540.x.

Badan Pusat Statistik (BPS). 2018. Produktivitas Bawang Merah Menurut Provinsi , 20132017. Jakarta.

Whipps, J.M. 2001. Microbial interactions and biocontrol in the rhizosphere. J. Exp. Bot. 52(suppl_1): 487-511. doi: 10.1093/jxb/ 52.suppl_1.487.

Wightwick, A., R. Walters, G. Allinson, S. Reichman, and N. Menzies. 2010. Environmental Risks of Fungicides Used in Horticultural Production Systems. In: Carisse, O., editor, Fungicides. InTech, Rijeka.

Wiyatiningsih, S., A. Wibowo, and E. Triwahyu. 2009. Keparahan penyakit moler pada enam kultivar bawang merah karena infeksi Fusarium oxysporum f.sp. cepae di tiga daerah sentra produksi. Seminar Nasional Akselerasi Pengembangan Teknologi Pertanian dalam Mendukung Revitalisasi Pertanian. Fakultas Pertanian \& LPPM UPN Veteran Jawa Timur, Surabaya.

Yadav, J., J.P. Verma, and K.N. Tiwari. 2011. Plant growth promoting activities of fungi and their effect on chickpea plant growth. Asian J. Biol. Sci., 4: 291-299. doi: 10.3923/ajbs/2011.291.299.

Zulaika. 2014. Pemanfaatan Cendawan Endofit dalam Pengendalian Busuk Umbi (Fusarium oxysporum) pada Bawang Merah (Allium cepa var. aggregatum). Institut Pertanian Bogor. Bogor. 